\title{
EDUCAÇÃO BÁSICA E EDUCAÇÃO PROFISSIONAL E TECNOLÓGICA: DUALIDADE HISTÓRICA E PERSPECTIVAS DE INTEGRAÇÃO
}

\author{
Dante Henrique Moura \\ Professor do CEFET-RN. Doutor em Educação \\ dante@cefetrn.br
}

\section{RESUMO}

O texto, a partir de uma revisão bibliográfica e de análise documental, visa alcançar dois objetivos básicos. Fazer uma retrospectiva histórica da dualidade estrutural entre a educação profissional e a educação básica, assim como a funcionalidade desse fenômeno ao tipo de desenvolvimento socioeconômico do país. Em seguida, se analisam possibilidades de articulação entre essas esferas educacionais com o fim de contribuir para o rompimento da mencionada dualidade. Conclui-se que, nos dias atuais, majoritariamente, o ensino médio privado e público, passa por uma crise de identidade e sentido. Conclui-se também que uma das formas de contribuir para a construção de sentido e identidade para o ensino médio é buscar a sua integração com a educação profissional e a ampliação gradativa e com qualidade da sua oferta nos sistemas públicos educacionais. Conclui-se ainda que essa expansão não visa, em princípio, a sua universalização. Entretanto, objetiva sedimentar as bases de uma futura educação tecnológica ou politécnica que deverá ser universal, pública, gratuita, laica e de qualidade, a ser implantada quando as condições objetivas da sociedade brasileira assim o permitir.

Palavras chave: educação básica. educação profissional. dualidade. integração

\section{EDUCACIÓN BÁSICA Y FORMACIÓN PROFESIONAL Y TECNOLÓGICA: DUALIDAD HISTÓRICA Y PERSPECTIVAS DE INTEGRACIÓN}

\section{RESUMEN}

El artículo parte de una revisión bibliográfica y de análisis documental en aras de lograr dos objetivos. Desarrollar una retrospectiva histórica acerca de la dualidad estructural entre la formación profesional y la educación básica y de la funcionalidad de ese fenómeno al tipo de desarrollo social y económico de Brasil. A continuación, se analizan las posibilidades de articulación entre esas esferas educativas con el propósito de de contribuir para la ruptura de la mencionada dualidad. Se concluye que, en la actualidad, mayoritariamente, la enseñanza media secundaria privada y pública, atraviesa una crisis de identidad y de sentido. Asimismo se concluye que una manera de contribuir para la construcción de sentido y de identidad propios para la enseñanza secundaria consiste en buscar su integración con la formación profesional técnica de nivel medio y la correspondiente ampliación gradual y con calidad de esa oferta formativa en los sistemas públicos educativos. Por fin, se concluye que esa expansión no tiene el objetivo inicial de tornarse universal. No obstante, el objetivo es sedimentar las bases de una futura educación tecnológica o politécnica que deberá ser universal, pública, gratuita, laica y de calidad, la cual será implantada cuando las condiciones materiales y objetivas de la sociedad brasileña permitan.

Palabras-clave: educación básica. formación profesional. dualidad. Integración. 


\section{EDUCAÇÃO BÁSICA E EDUCAÇÃO PROFISSIONAL E TECNOLÓGICA: DUALIDADE HISTÓRICA E PERSPECTIVAS DE INTEGRAÇÃO}

\section{Introdução}

Neste texto ${ }^{1}$, buscamos, a partir de uma revisão bibliográfica e de análise documental, alcançar dois objetivos básicos. O primeiro é fazer uma retrospectiva histórica da educação profissional, tendo como eixo estruturante a sua dualidade com a educação básica. Assim, essa vertente educacional, geralmente de caráter mais instrumental é permitida aos filhos das classes populares, enquanto a educação básica de caráter mais propedêutico é dirigida à formação das elites. O segundo objetivo é analisar as possibilidades de articulação entre a educação profissional e a educação básica com foco em uma proposta pedagógica que visa à integração entre o ensino médio e os cursos técnicos de nível médio com o fim de contribuir para o rompimento dessa dualidade estrutural.

Para alcançar esses objetivos, dividimos o texto em 6 partes. Nesta primeira, procuramos dar uma visão geral acerca do trabalho. Na seguinte, enfocamos, resumidamente, a história da educação profissional e do ensino médio no País. Nesse resgate histórico, adotamos como categoria estruturante a dualidade que sempre esteve presente na educação básica nacional, principalmente em sua etapa final, entre cultura geral e cultura técnica; e formação acadêmica/academicista e formação profissional profissional/formação para mercado. Na terceira parte do texto, apresentamos a discussão relativa à integração entre 0 ensino médio e a educação profissional como sendo uma nova chance para desconstruir a dualidade histórica entre educação básica propedêutica e formação profissional. Em seguida, discutimos os pressupostos que devem sustentar as propostas pedagógicas dessa formação integrada. Na quinta parte, apresentamos possibilidades de organização curricular dos cursos técnicos integrados ao ensino médio assim como algumas condições básicas necessárias à implementação dos cursos com a qualidade necessária. Na sexta e última parte, apresentamos algumas considerações finais acerca da análise desenvolvida ao longo do trabalho.

\section{Educação básica e educação profissional: a dualidade estrutural histórica}

A relação entre a educação básica e profissional no Brasil está marcada historicamente pela dualidade. Nesse sentido, até o século XIX não há registros de iniciativas sistemáticas que hoje possam ser caracterizadas como pertencentes ao campo da educação profissional. O que existia até então era a educação propedêutica para as elites, voltada para a formação de futuros dirigentes. Assim sendo, a educação cumpria a função de contribuir para a reprodução das classes sociais já que aos filhos das elites estava assegurada essa escola das ciências, das letras e das artes e aos demais lhes era negado o acesso.

Conforme consta em CEFET-RN (2005) e nos Parecer n ${ }^{0}$ 16/99-CEB/CNE, os primeiros indícios do que hoje se pode caracterizar como as origens da educação profissional surgem a partir do século XIX, mais precisamente em 1809, com a promulgação de um Decreto do Príncipe Regente, futuro D. João VI, criando o Colégio das Fábricas.

\footnotetext{
${ }^{1}$ Parte das discussões e análises apresentadas no presente trabalho também fazem parte do texto: Algumas reflexões e proposições acerca do Ensino Médio Integrado à Educação Profissional Técnica de Nível Médio (MOURA; BARACHO; PEREIRA; e SILVA, 2006)
} 
Em 1816, a criação da Escola de Belas Artes com o objetivo de articular o ensino das ciências e do desenho para os ofícios a serem realizados nas oficinas mecânicas; em 1861, a criação do Instituto Comercial no Rio de Janeiro, para ter pessoal capacitado para o preenchimento de cargos públicos nas secretarias de Estado; nos anos 1940 do século XIX, a construção de dez Casas de Educandos e Artífices em capitais brasileiras, sendo a primeira em Belém do Pará; em 1854, a criação de estabelecimentos especiais para menores abandonados, chamados de Asilos da Infância dos Meninos Desvalidos que ensinavam as primeiras letras e encaminhavam os egressos para oficinas públicas e particulares, através do Juizado de Órfãos. Segundo Manfredi,

\footnotetext{
Crianças e jovens em estado de mendicância eram encaminhados para essas casas, onde recebiam instrução primária [...] e aprendiam alguns dos seguintes ofícios: tipografia, encadernação, alfaiataria, tornearia, carpintaria, sapataria, etc. Concluída a aprendizagem, o artífice permanecia mais três anos no asilo, trabalhando nas oficinas, com a dupla finalidade de pagar sua aprendizagem e formar um pecúlio que lhe era entregue no final do triênio. (MANFREDI, 2002, p. 76-77, citado por MACIEL, 2005, p. 31).
}

A educação profissional no Brasil tem, portanto, a sua origem dentro de uma perspectiva assistencialista com o objetivo de "amparar os órfãos e os demais desvalidos da sorte”, ou seja, de atender àqueles que não tinham condições sociais satisfatórias, para que não continuassem a praticar ações que estavam na contra-ordem dos bons costumes.

Ainda no século XIX, foram criadas sociedades civis destinadas a dar amparo a crianças órfãs e abandonadas, possibilitando-lhes uma base de instrução teórica e prática e iniciando-as no ensino industrial. Entre estas sociedades, as mais importantes foram os Liceus de Artes e Ofícios do Rio de Janeiro (1858), de Salvador (1872), do Recife (1880), de São Paulo (1882), de Maceió (1884) e de Ouro Preto (1886).

Essa lógica assistencialista com que surge a educação profissional é perfeitamente coerente com uma sociedade escravocrata originada de forma dependente da coroa portuguesa, que passou pelo domínio holandês e recebeu a influência de povos franceses, italianos, poloneses, africanos e indígenas, resultando em uma ampla diversidade cultural e de condições de vida ao longo da história - uma marca concreta nas condições sociais dos descendentes de cada um destes segmentos.

O início do Século XX trouxe uma novidade para a história da educação profissional do país quando houve um esforço público de organização da formação profissional, modificando a preocupação mais nitidamente assistencialista de atendimento a menores abandonados e órfãos, para a da preparação de operários para o exercício profissional. Assim, em 1906, o ensino profissional passou a ser atribuição do Ministério da Agricultura, Indústria e Comércio, mediante a busca da consolidação de uma política de incentivo para preparação de ofícios dentro destes três ramos da economia.

Em 23 de setembro de 1909, Nilo Peçanha aproveitando as idéias defendidas por Afonso Pena, criou as Escolas de Aprendizes Artífices e instalou dezenove delas em 1910 nas várias unidades da Federação que eram destinadas “aos pobres e humildes”. Estes Liceus eram semelhantes aos Liceus de Artes e Ofícios e voltados para o ensino industrial, sendo custeados pelo Estado Brasileiro. Neste mesmo ano, foi organizado o ensino agrícola para capacitar "chefes de cultura, administradores e capatazes". Observa-se claramente o caráter elitista e de reprodução da estrutura social estratificada da referida organização. 
A criação das Escolas de Aprendizes Artífices e do ensino agrícola evidenciou um grande passo ao redirecionamento da EP no país, pois ampliou o seu horizonte de atuação para atender necessidades emergentes dos empreendimentos nos campos da agricultura e da indústria.

Nesse contexto, chega-se à década de 30 do século XX com a educação básica brasileira estruturada de uma forma completamente dual na qual a diferenciação entre os percursos educativos dos filhos das elites e dos filhos da classe trabalhadora ocorria desde o curso primário. Assim, resumidamente, a educação básica era estruturada conforme descrito a seguir.

Havia um curso primário com duração de 4 anos para aqueles cujo percurso tinha como fim a educação superior. Alternativamente, existiam os cursos rural ou profissional destinado às crianças das classes populares (KUENZER, 1997).

Ao curso primário poderiam suceder o ginasial, com duração de seis anos, o normal, antecedido de dois anos de adaptação ou o curso técnico comercial, antecedido de três anos de curso propedêutico. Para os concluintes do curso rural sucedia, obrigatoriamente, o curso básico agrícola, enquanto o curso complementar era oferecido aos egressos do curso profissional, ambos com 2 anos de duração (KUENZER, 1997).

O curso normal, o técnico comercial, o básico agrícola e o complementar tinham nitidamente caráter terminal e eram voltados para as necessidades imediatas dos setores produtivos. Dessa forma, os concluintes desses cursos não podiam continuar os estudos em nível superior, acessível apenas aos egressos da $5^{\mathrm{a}}$ série do ensino ginasial. Enquanto isso, os concluintes da $6^{\mathrm{a}}$ série do ginasial recebiam o título de bacharel em Ciências e Letras. Não havia, nesse período, o que hoje se denomina ensino médio, de modo que a mediação entre o ginasial e o ensino superior era feita por meio de estudos livres e exames.

As décadas de 30 e 40 do século XX foram marcadas por grandes transformações políticas e econômicas da sociedade brasileira com conseqüências profundas sobre a educação.

Nesse período, em 1930, foi criado o primeiro ministério no âmbito da educação Ministério da Educação e Saúde Pública². Em 1931, foi criado o Conselho Nacional de Educação e efetivada uma reforma educacional. Desta época, destacam-se os Decretos Federais $n^{0} 19.890 / 31$ e $n^{0} 21.241 / 32$, que regulamentaram a organização do ensino secundário e o de $\mathrm{n}^{0}$ 20.158/31, que organizou o ensino comercial e regulamentou a profissão de contador.

Outro fato importante a ser relatado, ocorrido neste contexto, foi o Manifesto dos Pioneiros da Educação Nova. Esse Manifesto se dizia assumir a perspectiva de uma escola democrática que pudesse proporcionar oportunidades para todos, tanto no que dizia respeito a uma cultura geral, como na possibilidade de especializações. Entretanto, a proposta organizava a educação em duas grandes categorias: atividades de humanidades e ciências (de natureza mais intelectual) e cursos de caráter técnico (de natureza mecânica e

\footnotetext{
2 Na verdade, no início do período republicano houve uma primeira tentativa de criação de um órgão que incluía a esfera educacional - Secretaria da Instrução, Correios e Telégrafos. Entretanto, o órgão teve vida curta, de 1890 a 1892, e, além disso, seu funcionamento foi pouco estudado de modo que não há registro de que tenha desenvolvido alguma atividade significativa no domínio da educação (FÁ VERO, 2001).
} 
manual). Desse modo, percebe-se claramente, mais uma vez, a distinção entre aqueles que pensam e aqueles que executam as atividades.

Convém, ainda, ressaltar que a V Conferência Nacional de Educação, realizada em 1933, refletiu-se, através dos seus resultados, na Assembléia Nacional Constituinte que ocorreu no mesmo ano e reforçou a idéia de responsabilidade do Estado para com a educação. Desse modo, a Constituição Brasileira de 1934 inaugurou uma política de educação, com o estabelecimento das competências da União em traçar as diretrizes nacionais e fixar o plano nacional de educação. Além disso, pela primeira vez uma constituição criou a vinculação de recursos à educação.

Por outro lado, a Constituição de 1937, já no período ditatorial do governo Vargas, apresentou um retrocesso em relação à de 1934, pois dentre outros aspectos, acabou com a vinculação constitucional de recursos destinados à educação. É nela que aparece pela primeira vez a definição de “escolas vocacionais e pré-vocacionais” (Art. 129).

Art 129 - A infância e à juventude, a que faltarem os recursos necessários à educação em instituições particulares, é dever da Nação, dos Estados e dos Municípios assegurar, pela fundação de instituições públicas de ensino em todos os seus graus, a possibilidade de receber uma educação adequada às suas faculdades, aptidões e tendências vocacionais.

$\mathrm{O}$ ensino pré-vocacional profissional destinado às classes menos favorecidas é em matéria de educação o primeiro dever de Estado. Cumpre-lhe dar execução a esse dever, fundando institutos de ensino profissional e subsidiando os de iniciativa dos Estados, dos Municípios e dos indivíduos ou associações particulares e profissionais. (CONSTITUIÇÃO FEDERAL DE 1937, Art. 129)

Como se vê, eram escolas pobres para os pobres e destinavam-se a preparar os filhos dos operários ou de seus associados para os ofícios, cujos cursos deveriam ser desenvolvidos com a colaboração dos sindicatos e das indústrias.

Note-se que esta demanda foi decorrente do processo de industrialização que vinha sendo desencadeado a partir de 1930 e exigia um contingente de profissionais mais especializados para a indústria, o comércio e a prestação de serviços. Esse fortalecimento da indústria nacional é potencializado pela $2^{\mathrm{a}}$ grande guerra mundial, pois no período prébélico e durante o conflito as grandes economias envolvidas - países centrais da Europa, Estados Unidos e Japão - concentraram todo seu esforço produtivo na indústria bélica, abrindo espaço para que as economias emergentes avançassem em seus processos de industrialização, no que ficou conhecido como o modelo de substituição de importações.

É nesse momento que no Brasil se fortalece a nova burguesia industrial em substituição às oligarquias cafeeiras, profundamente afetadas pela crise da agricultura do café dos anos 20 e do crash da bolsa de Nova Iorque, em 1929.

Esse processo de industrialização e modernização das relações de produção da sociedade brasileira exigiu um posicionamento mais efetivo das camadas dirigentes com relação à educação nacional, como resposta a essas demandas, foram promulgados diversos Decretos-Lei para normatizar a estruturação da educação.

Este conjunto de decretos ficou conhecido como as Leis Orgânicas da Educação Nacional - a Reforma Capanema, em função do então ministro da educação, Gustavo Capanema. Os 
principais decretos foram os seguintes: Decreto $n^{0} 4.244 / 42$ - Lei Orgânica do Ensino Secundário; Decreto $n^{0}$ 4.073/42 - Lei Orgânica do Ensino Industrial; Decreto $n^{0}$ 6.141/43 - Lei Orgânica do Ensino Comercial; Decreto N N 8.529/46 - Lei Orgânica do Ensino Primário; Decreto $n^{0}$ 8.530/46 - Lei Orgânica do Ensino Normal e; Decreto $n^{0}$ 9.613/46 Lei Orgânica do Ensino Agrícola. Além disso, o Decreto-lei 4.048/1942 - cria o Serviço Nacional de Aprendizagem Industrial - SENAI, que deu origem ao que hoje se conhece como Sistema "S"

O conjunto desses Decretos-Lei evidencia a importância que passou a ter a educação dentro do país e, em especial, a educação profissional, pois foram definidas leis específicas para a formação profissional em cada ramo da economia e para a formação de professores em nível médio.

Entretanto, reafirmava-se a dualidade, pois o acesso ao ensino superior, via processo seletivo, continuava ocorrendo em função do domínio dos conteúdos gerais, das letras, das ciências e das humanidades, assumidos como únicos conhecimentos válidos para a formação da classe dirigente (KUENZER, 1997).

Desse modo, após a Reforma Capanema, a educação básica e a profissional passaram a se estruturar e relacionar conforme descrito a continuação. Na educação básica desaparecem os cursos de complementação e surge uma nova etapa, os cursos médios de $2^{0}$ ciclo (atual ensino médio), denominados de cursos colegiais, com duas variantes: científico e clássico, ambos voltados para preparar cidadãos para o ingresso no ensino superior.

Assim sendo, a educação brasileira denominada regular, fica estruturada em dois níveis, a educação básica e a superior. A educação básica divide-se em duas etapas. O curso primário, com duração de 5 anos, e o secundário, subdividido em ginasial, com duração de 4 anos, e o colegial, com 3 anos.

A vertente profissionalizante parte final do ensino secundário era constituída pelos cursos normal, industrial técnico, comercial técnico e agrotécnico. Todos com o mesmo nível e duração do colegial, entretanto não habilitavam para o ingresso no ensino superior.

Apesar dessa diferenciação, é nesse contexto que surge pela primeira vez uma possibilidade de aproximação entre o ramo secundário propedêutico (o colegial, com suas variantes científico e clássico) e os cursos profissionalizantes de nível médio, por meio de exames de adaptação.

Também importa ressaltar que a criação do SENAI, em 1942, seguida do SENAC, em 1946, e dos demais "S” ao longo das décadas seguintes, revelam a opção governamental de repassar à iniciativa privada a tarefa de preparar "mão-de-obra” para o mundo produtivo. Assim, a partir dessa lógica, o ensino secundário e o normal formariam as elites condutoras do país e o ensino profissional formaria adequadamente os filhos de operários para as artes

\footnotetext{
${ }^{3}$ Para Grabowski (2005), integram o Sistema "S”: SENAI - Serviço Nacional de Aprendizagem Industrial, SESI - Serviço Social da Indústria, SENAC - Serviço Nacional de Aprendizagem Comercial, SESC Serviço Social do Comércio, SENAT - Serviço Nacional de Aprendizagem dos Transportes, SEST - Serviço Social dos Transportes, SENAR - Serviço Nacional de Aprendizagem Rural, SESCOOP - Serviço Nacional de Aprendizagem do Cooperativismo e SEBRAE - Serviço Brasileiro de Apoio às Micro e Pequenas Empresas.
} 
e os ofícios. Portanto, ratifica-se o caráter dualista da educação e a sua função reprodutora da estrutura social.

Outra fase de grande efervescência política em torno das questões educacionais foi o período que antecedeu a vigência da primeira Lei de Diretrizes e Bases da Educação Nacional - LDB. O projeto de Lei começou a tramitar no Congresso Nacional em 1948, portanto na fase de redemocratização do País pós Estado Novo. Essa Lei $n^{0} 4.024$ (a primeira LDB) só entrou em vigor em 1961.

Todo o período de trâmite e discussões foi extremamente rico em debates acerca da sociedade brasileira que estava em conflito entre modelos distintos de desenvolvimento.

Nesse contexto, terminada a $2^{\mathrm{a}}$ guerra, volta a dependência às economias hegemônicas mundiais, entretanto a aceleração da diversificação industrial continua gerando o Estado desenvolvimentista-populista sustentado na aliança entre o empresariado, desejoso de expansão, e setores populares com aspirações de maior participação econômica e na política. Nessa euforia desenvolvimentista surge o capital estrangeiro que, em um primeiro momento, não parecia trazer nenhuma ameaça ao modelo nacional-desenvolvimentista.

Entretanto, o pacto desenvolvimentista se deteriora por diversas razões: pressão das classes subalternas aviltadas pelos pequenos salários já que o modelo revelou-se extremamente concentrador de riquezas; parte das classes médias (profissionais liberais, forças armadas) empobrecidas pela inflação sentem-se excluídos das decisões pelo Estado populista; e o capital estrangeiro vê no modelo vigente uma barreira aos seus interesses de absorção do mercado interno.

Nesse contexto, consolida-se a polarização entre os setores populares e, até certo ponto, o próprio Estado versus um grupo heterogêneo composto por grandes parcelas da classe média, do capital estrangeiro e das antigas oligarquias (FREITAG, 1979).

A política educacional reflete esses conflitos de poder, de modo que a luta em torno à criação da LDB ocorre em meio à polarização de interesses entre os setores populares e populistas que pleiteavam, entre outros aspectos, a extensão da rede escolar gratuita (primário e secundário); e equivalência entre ensino médio propedêutico e profissionalizante, com possibilidade de transferência de um para outro, ambos incorporados na proposta do Ministro Clemente Mariani (FREITAG, 1979).

Enquanto isso, os setores vinculados às classes hegemônicas, cujos interesses estavam materializados no substitutivo Lacerda (de Carlos Lacerda) reivindicavam a redução da ação da sociedade política sobre a escola. Desse modo, defendiam que a educação fosse ministrada predominantemente em escolas privadas. Na visão deles, as escolas públicas deveriam ser complementares para quem não "quisesse" matricular os filhos na escola particular, de forma que os pais teriam "liberdade" de escolher a escola dos filhos. Também incorporavam a defesa da subvenção do Estado para as escolas, inclusive às privadas. Justificavam a proposta alegando que o Estado precisava assegurar a boa educação dos futuros cidadãos, independentemente da escola "escolhida" pelas famílias (FREITAG, 1979). Finalmente, também era advogado por esse grupo, o fato de que a obrigação do Estado de subvencionar as escolas privadas não lhe daria o direito de fiscalizar essa rede, em nome da liberdade de ensino. 
Foi nesse contexto de conflitos que tramitou durante 13 anos o Projeto de Lei da primeira LDB do País. Evidentemente, o resultado, ou seja, a LDB refletiu as contradições da sociedade em geral e da esfera educacional em particular.

Desse modo, a primeira LDB envolve todos os níveis e modalidades acadêmica e profissional de ensino e, por um lado, proporciona a liberdade de atuação da iniciativa privada no domínio educacional, mas, por outro, dá plena equivalência entre todos os cursos do mesmo nível sem a necessidade de exames e provas de conhecimento visando à equiparação.

De tal modo, tanto os estudantes provenientes do colegial como os do ensino profissional poderiam dar continuidade de estudos no ensino superior. Este fato colocava, formalmente, um fim na dualidade de ensino.

É importante frisar que essa dualidade só acabava formalmente já que os currículos se encarregavam de mantê-la, uma vez que a vertente do ensino voltada para a continuidade de estudos em nível superior e, portanto, destinada às elites, continuava privilegiando os conteúdos que eram exigidos nos processos seletivos de acesso à educação superior, ou seja, as ciências, as letras e as artes. Enquanto isso, nos cursos profissionalizantes, esses conteúdos eram reduzidos em favor das necessidades imediatas do mundo do trabalho.

Essa primeira LDB estruturou, em seu primeiro momento, a educação brasileira em três graus. Educação de grau primário, igual para todos os estudantes e obrigatória a partir dos 7 anos de idade, composta de: escola pré-primária para crianças menores de 7 anos; curso primário com 4 séries anuais, seguido do exame de admissão ao ginasial, para crianças de 7 a 10 anos.

Educação de grau médio, composta de dois ciclos: ginasial (11 aos 14 anos); e colegial (15 aos 17 anos), ambos abrangendo cursos secundários, técnicos e de formação de professores para o primário e pré-primário, sendo os dois últimos de caráter profissionalizante e o primeiro de cunho propedêutico.

Educação de grau superior, acessível a todos os concluintes da educação de grau médio, mediante habilitação em concurso de habilitação.

No Brasil, a década dos anos 1960, período em que entrou em vigor a primeira LDB, é marcada pelo Golpe Civil Militar de1964. A educação passou a ser considerada prioritária para o Governo pois, de acordo com Niskier (1974, p. 19), “a meta a ser alcançada é a transformação do Brasil numa grande potência, no espaço de uma geração, através do que se constitui o modelo brasileiro do desenvolvimento”. Nesse contexto, a educação aparece como a grande alavancadora do desenvolvimento, sendo utilizada como meio de inculcação da ideologia do governo autoritário.

Assim chega-se aos 1970, ainda sob o regime ditatorial. Em 1971 há uma profunda reforma da educação básica promovida pela Lei $n^{0} 5.692 / 71$ - Lei da Reforma de Ensino de $1^{\circ}$ e $2^{\circ}$ graus -, que se constituiu em uma tentativa de estruturar a educação de nível médio brasileiro como sendo profissionalizante para todos.

As mudanças concentraram-se na educação de grau primário e de grau médio, mais especificamente nos cursos que até então se denominavam primário, ginasial e colegial, os 
quais foram transformados em $1^{\circ}$ grau e $2^{\circ}$ grau, sendo que o $1^{\circ}$ grau agrupou o primário e o ginasial e o $2^{\circ}$ grau absorveu o colegial. $\mathrm{O} 1^{\circ}$ grau tinha 8 anos de duração (7 a 14 anos de idade), dividido em primeiro grau menor de $1^{\mathrm{a}}$ a $4^{\mathrm{a}}$ série e primeiro grau maior de $5^{\mathrm{a}}$ a $8^{\mathrm{a}}$ série -. Enquanto o $2^{\circ}$ grau era realizado em três anos (15 aos 17 anos de idade).

Três aspectos merecem grande destaque nessa reforma. Um deles é o fato de que pela primeira vez a escolarização dos 11 aos 14 anos ( $5^{\mathrm{a}}$ a $8^{\mathrm{a}}$ série do $1^{\mathrm{o}}$ grau) integra a fase inicial dos estudos e não mais o ensino secundário. Outro é que juntamente com a criação do $1^{0}$ grau houve a extinção do exame de admissão ao ginásio, existente no âmbito da Lei $n^{0} 4.024 / 1961$ e que, na prática, se constituía em uma barreira ao prosseguimento de estudos, especialmente dos filhos das classes populares. Esses são, sem dúvida, grandes avanços e apontam para a elevação do grau de escolarização mínima da população, anteriormente circunscrito às quatro primeiras séries.

Outro aspecto extremamente relevante, e, ao mesmo tempo, polêmico, foi o caráter de profissionalização obrigatória do ensino de $2^{\circ}$ grau. Uma conjugação de fatores produziu essa compulsoriedade. Por um lado, um governo autoritário com elevados índices de aceitação popular, evidentemente interessado em manter-se dessa forma. Para isso era necessário dar respostas à crescente demanda das classes populares por acesso a níveis mais elevados de escolarização, o que acarretava uma forte pressão pelo aumento de vagas no ensino superior.

Esse mesmo governo, tinha seu projeto de desenvolvimento do Brasil calcado no endividamento externo voltado para financiar uma nova fase de industrialização, o que ficou conhecido como o milagre brasileiro. Esse "milagre" demandava por "mão-de-obra" qualificada (técnicos de nível médio) para atender a tal crescimento.

Assim, a opção política do governo, sustentada no modelo de desenvolvimento econômico por ele potencializado, foi dar uma resposta diferente às demandas educacionais das classes populares, mas que pudesse "atendê-las". Utilizou-se, então, da via da formação técnica profissionalizante a nível de $2^{\circ}$ grau, o que "garantiria" a inserção no "mercado de trabalho” - em plena expansão em função dos elevados índices de desenvolvimento.

Analisando essa reforma a partir da categoria de análise central adotada neste trabalho - a dualidade estrutural entre a educação básica e a educação profissional-, conclui-se, em princípio, que do ponto de vista formal, a Lei $n^{0} 5.692 / 71$ surge no sentido de eliminar tal dualidade ao tornar compulsória a profissionalização ao nível do $2^{\circ}$ grau - última etapa da educação básica. Ou dito de outra forma, segundo a Lei o ensino de $2^{0}$ grau seria profissionalizante, a partir de então, em todas as escolas públicas e privadas do país.

Entretanto, uma análise histórica da sociedade e, em particular, da educação brasileira nesse período, revela que a realidade foi construída de forma distinta. Em primeiro lugar, na prática, a compulsoriedade se restringiu ao âmbito público, notadamente nos sistemas de ensino dos estados e no federal. Enquanto isso, as escolas privadas continuaram, em sua absoluta maioria, com os currículos propedêuticos voltados para as ciências, letras e artes visando o atendimento às elites.

Nos sistemas estaduais de ensino a profissionalização compulsória foi amplamente problemática e não foi implantada completamente. Em primeiro lugar, porque a concepção curricular que emanava da Lei empobrecia a formação geral do estudante em favor de uma profissionalização instrumental para o "mercado de trabalho", sob a alegação da importância da relação entre teoria e prática para a formação integral do cidadão. 
Entretanto, de forma incoerente com esse discurso, ao invés de se ampliar a duração do $2^{\circ}$ grau para incluir os conteúdos da formação profissional de forma integrada aos conhecimentos das ciências, das letras e das artes, o que houve foi a redução dos últimos em favor dos primeiros, os quais assumiram um caráter instrumental e de baixa complexidade, uma vez que, dentre outros aspectos, não havia a base científica que permitisse caminhar na direção de conhecimentos mais complexos inerentes ao mundo do trabalho. E isto não ocorreu por acaso, pois fazia parte da própria concepção de desenvolvimento do País e da reforma educacional em questão.

Além disso, a falta de um adequado financiamento e de formação de professores, decorrente de decisão política do mesmo governo que implantou autoritariamente a reforma, contribuiu para que a profissionalização nos sistemas públicos estaduais ocorresse predominantemente em áreas em que não havia demandas por laboratórios, equipamentos, enfim por toda uma infra-estrutura específica e especializada.

Dessa forma, em linhas gerais, nesses sistemas de ensino proliferaram-se cursos de Técnico em Administração, Técnico em Contabilidade, Técnico em Secretariado etc. Isso provocou uma rápida saturação de profissionais oriundos desses cursos no mundo do trabalho e, em conseqüência, a banalização da formação e o desprestígio dos mesmos.

Por outro lado, nas ETFs e EAFs, escolas técnicas e agrotécnicas federais respectivamente (instituições que deram origem aos atuais CEFETs), a realidade foi construída de maneira distinta. Tais escolas consolidaram sua atuação principalmente na vertente industrial, no caso das ETFs, por meio dos cursos de Técnico em Mecânica, Técnico em Eletrotécnica, Técnico em Mineração, Técnico em Geologia, Técnico em Edificações, Técnico em Estradas etc. e no ramo Agropecuário, no caso das EAFs.

Essa atuação foi viabilizada precisamente pelo que faltou aos sistemas estaduais de ensino, ou seja, financiamento adequado e corpo docente especializado, o que também teve e continua tendo uma estreita relação com o financiamento, pois a política de remuneração docente na esfera federal é muita distinta daquela dos demais sistemas públicos de educação.

Nesse processo, as ETFs consolidam-se ainda mais como referência de qualidade na formação de técnicos de nível médio. Assim, os profissionais egressos dessas instituições compõem quadros importantes de grandes empresas nacionais e internacionais ${ }^{4}$.

Nessa perspectiva, cabe mencionar o grande contingente de técnicos de nível médio formados nas ETFs que atuam na PETROBRAS, na Vale do Rio Doce, nas concessionárias de energia elétrica, nas concessionárias de serviços de abastecimento de água e saneamento, nas empresas de telecomunicações e em muitas outras empresas de pequeno, médio e grande porte. Igualmente, significativa é a quantidade de estudantes egressos das ETFs que continuaram seus estudos em nível superior, imediatamente após a conclusão do respectivo curso técnico ou posteriormente.

Esse último dado revela inclusive que as ETFs, em função das condições diferenciadas que tiveram, na maioria dos casos não mantiveram seus currículos nos limites restritos de instrumentalidade para o mundo do trabalho, estabelecidos pela Lei n ${ }^{0}$ 5.692/1971.

\footnotetext{
${ }^{4}$ Fenômeno semelhante ao ocorrido nas ETFs aconteceu nas Escolas Agrotécnicas Federais - EAFs.
} 
Desse modo, constata-se que por um lado, o currículo das escolas estaduais estava empobrecido pela presença de conteúdos profissionalizantes no $2^{\circ}$ grau em detrimento dos conhecimentos das ciências, das letras e das artes, sendo esses últimos indispensáveis a quem desejasse aceder ao ensino superior. Paralelamente, era cada vez maior o acesso das classes populares a essa escola pública, inclusive, pela extinção do exame de admissão ao ginásio estabelecido pela Lei $\mathrm{n}^{0} 5.692 / 1971$. Por outro lado, as escolas privadas não se submeteram aos preceitos da reforma, ou seja, não profissionalizaram o $2^{\circ}$ grau. $\mathrm{Na}$ verdade, a reforma foi "simplesmente descartada (com raras exceções) pela rede privada devido ao seu elevado custo” (GERMANO, 2005, p. 187).

Diante desse quadro, observa-se um acentuado movimento dos filhos da classe média das escolas públicas para as privadas na busca de garantir uma formação que lhes permitisse continuar os estudos no nível superior. Esse movimento, alimenta o processo de desvalorização da escola pública estadual e municipal, pois era e continua sendo a classe média que tem algum poder de pressão junto às esferas de governo.

Evidentemente é necessário relativizar essa opção da classe média, pois afinal estava em jogo a busca da garantia de uma melhor educação para os seus filhos. Mas, ao mesmo tempo, não se pode perder de vista que a alternativa poderia ter sido mais solidária, ou seja, juntar-se às classes populares que estavam chegando à escola pública e fortalecer a pressão por melhorias na educação pública, gratuita e de qualidade para todos. O fato que é todo esse contexto contribuiu para gerar um ciclo negativo, o qual ainda não foi rompido, de deterioração da escola básica pública brasileira e que reforça a dualidade entre educação básica e educação profissional.

Paralelamente, a Lei $\mathrm{n}^{0}$ 5.692/1971 foi sendo gradualmente flexibilizada. Inicialmente pelo Parecer $n^{0}$ 76/1975, do Conselho Federal de Educação, seguido da Lei $n^{0} 7.044 / 1982$. O conjunto dessas modificações operou no sentido de facultar a obrigatoriedade da profissionalização em todo o ensino de $2^{0}$ grau.

Na prática, "a velha dualidade ressurgiu no âmbito da legislação com todo o seu vigor, reafirmando-se novamente na oferta propedêutica [...] como a via preferencial para ingresso no nível superior, permanecendo os velhos ramos [...] como vias preferenciais de acesso ao mundo do trabalho" (KUENZER, 1997, p.24).

Nesse processo, a profissionalização obrigatória vai desvanecendo-se, de modo que ao final dos anos 1980 e primeira metade dos anos 1990, quando, após a promulgação da Constituição Federal de 1988, ocorre no Congresso Nacional o processo que culmina com a entrada em vigor de uma nova LDB, a Lei $n^{0} 9.394 / 1996$, já quase não há mais $2^{0}$ grau profissionalizante no país, exceto nas ETFs, EAFs e alguns poucos sistemas estaduais de ensino.

Igualmente ao trâmite que resultou na primeira LDB - a de 1.961-, no processo mais recente o país estava novamente saindo de um período ditatorial e tentando reconstruir o estado de direito, de modo que os conflitos não eram pequenos em torno de projetos societários distintos.

Especificamente na esfera educacional, a principal polêmica continuou sendo o conflito entre os que advogam por uma educação pública, gratuita, laica e de qualidade para todos, independentemente da origem socioeconômica, étnica, racial etc. e os defensores da submissão dos direitos sociais em geral e, particularmente, da educação à lógica da 
prestação de serviços sob a argumentação da necessidade de diminuir o estado que gasta muito e não faz nada bem feito.

Nesse embate, prevaleceu a lógica de mercado e, portanto, a iniciativa privada pode atuar livremente na educação em todos os níveis, conforme garantido pela Constituição Federal de 1988 e ratificado pela LDB de $1996^{5}$.

Retomando, entretanto, o objeto central de análise deste texto -a dualidade estrutural do ensino médio brasileiro-, encontra-se o seguinte quadro na gênese da nova LDB.

No processo de elaboração da nova Lei, ressurge o conflito da dualidade (FRIGOTTO, CIAVATTA e RAMOS, 2005). De um lado a defesa da formação profissional lato sensu integrada à formação geral nos seus múltiplos aspectos humanísticos e científicotecnológicos constante no primeiro projeto de Lei de LDB, apresentado pelo Deputado Federal Otávio Elísio, que tratava o ensino médio da seguinte forma:

\begin{abstract}
A educação escolar de $2^{\circ}$ grau será ministrada apenas na língua nacional e tem por objetivo propiciar aos adolescentes a formação politécnica necessária à compreensão teórica e prática dos fundamentos científicos das múltiplas técnicas utilizadas no processo produtivo (BRASIL. 1991, Art. 38 citado por FRIGOTTO, CIAVATTA E RAMOS, 2005).
\end{abstract}

Nessa proposta, o papel do ensino médio estaria orientado à recuperação da relação entre conhecimento e a prática do trabalho, o que denotaria explicitar como a ciência se converte em potência material no processo produtivo. Dessa forma, "seu horizonte deveria ser o de propiciar aos alunos o domínio dos fundamentos das técnicas diversificadas utilizadas na produção, e não o mero adestramento em técnicas produtivas. Não se deveria, então, propor que o ensino médio formasse técnicos especializados, mas sim politécnicos." (FRIGOTTO, CIAVATTA e RAMOS, 2005, p. 35).

Nesse contexto, a politecnia relaciona-se com "domínio dos fundamentos científicos das diferentes técnicas que caracterizam o processo de trabalho moderno" (SAVIANI, 2003, p. 140). De acordo com essa visão, a educação escolar, particularmente o ensino médio deveria propiciar aos estudantes a possibilidade de (re)construção dos princípios científicos gerais sobre os quais se fundamentam a multiplicidade de processos e técnicas que dão base aos sistemas de produção em cada momento histórico.

Essa perspectiva de formação integral foi perdendo-se gradativamente em função da mesma correlação de forças já mencionada anteriormente ao se tratar do embate entre educação pública e educação privada. Desse modo, o texto finalmente aprovado pelo Congresso nacional em 1996 consolida, mais uma vez, a dualidade entre o ensino médio e a educação profissional.

O texto é minimalista e ambíguo em geral e, em particular, no que se refere a essa relação - ensino médio e educação profissional. Assim, o ensino médio está no Capítulo II que é destinado à educação básica, constituindo-se em sua última etapa. Enquanto isso, a educação profissional está em capítulo distinto (Capítulo III), constituído por três pequenos artigos.

\footnotetext{
${ }^{5}$ Análises mais profundas sobre a questão educacional brasileira na Constituinte de 1988 e na LDB de 1996 podem ser encontradas em Fávero (2005) e Machado (1997), dentre outros.
} 
Como a educação brasileira é estruturada na nova LDB em dois níveis - educação básica e educação superior, e a educação profissional não está em nenhum dos dois, consolida-se a dualidade de forma bastante explícita. Dito de outra maneira, a educação profissional não faz parte da estrutura da educação regular brasileira. É considerada como algo que vem em paralelo ou como um apêndice e, na falta de uma denominação mais adequada, resolveu-se tratá-la como modalidade, o que efetivamente não é correto.

Apesar disso, no $\S 2^{\circ}$ do Artigo 36 - Seção IV do Capítulo II - que se refere ao ensino médio estabelece- se que "O ensino médio, atendida a formação geral do educando, poderá prepará-lo para o exercício de profissões técnicas.” (grifo nosso)

Por outro lado, no Artigo 40 - Capítulo III - , está estabelecido que “a educação profissional será desenvolvida em articulação com o ensino regular ou por diferentes estratégias de educação continuada, em instituições especializadas ou no ambiente de trabalho.” (grifo nosso)

Esses dois pequenos trechos da Lei são emblemáticos no sentido de explicitar o seu caráter minimalista e ambíguo. Esses dispositivos legais evidenciam que quaisquer possibilidades de articulação entre o ensino médio e a educação profissional podem ser realizadas, assim como a completa desarticulação entre eles.

Cabe ressaltar que essa redação não é inocente e desinteressada. Ao contrário, objetiva consolidar a separação entre o ensino médio e a educação profissional, o que já era objeto do Projeto de Lei de iniciativa do poder executivo - governo FHC - que ficou conhecido como o PL 1603, o qual tramitava no Congresso Nacional em 1996 anteriormente à aprovação e promulgação da própria LDB.

O conteúdo desse PL 1603 que, dentre outros aspectos, separava obrigatoriamente o ensino médio da educação profissional encontrou ampla resistência das mais diversas correntes políticas dentro do Congresso Nacional e gerou uma mobilização contrária da comunidade acadêmica, principalmente, dos grupos de investigação do campo educação e trabalho, das ETFs e dos Centros Federais de Educação Tecnológica - CEFETs, principalmente das correspondentes entidades sindicais.

Em função dessa resistência e da iminência da aprovação da própria LDB no Congresso Nacional o governo FHC, estrategicamente, diminui a pressão com relação ao trâmite do PL 1603, uma vez que a redação dos artigos 36 - ensino médio - e 39 a 42 - educação profissional - possibilitavam a regulamentação na linha desejada pelo governo por meio de Decreto do Presidente da República. Foi isso o que realmente veio a ocorrer em abril de 1997, poucos meses após a promulgação da LDB ocorrida em dezembro de 1996.

Dessa forma, o conteúdo do PL 1603 foi praticamente todo contemplado no Decreto $\mathrm{n}^{0}$ 2.208/1997. Assim sendo, o governo federal de então fez prevalecer o seu intuito de separar o ensino médio da educação profissional sem ter que enfrentar o desgaste de tramitar um Projeto de Lei ao qual havia ampla resistência, caracterizando seu caráter antidemocrático nesse episódio.

A partir desse instrumento legal o ensino médio retoma legalmente um sentido puramente propedêutico, enquanto os cursos técnicos, agora obrigatoriamente separados do ensino médio, passam a ser oferecidos de duas formas. Uma delas é a Concomitante ao ensino médio. Nesse caso o estudante pode fazer ao mesmo tempo o ensino médio e o curso 
técnico, mas com matrículas e currículos distintos, podendo os dois cursos serem feitos na mesma instituição (concomitância interna) ou em diferentes instituições (concomitância externa). A outra forma é a Subseqüente, destinada a quem já concluiu o ensino médio e, portanto, a educação básica.

Juntamente com o Decreto $n^{0} 2.208 / 1997$, que estabeleceu as bases da reforma da educação profissional, o governo federal negocia empréstimo junto ao Banco Interamericano de Desenvolvimento (BID) com o objetivo de financiar a mencionada reforma como parte integrante do projeto de privatização do estado brasileiro em atendimento à política neoliberal, determinada desde os países hegemônicos de capitalismo avançado e das grandes corporações transnacionais. Esse financiamento é materializado por meio do Programa de Expansão da Educação Profissional - PROEP.

Apesar da crítica radical que merece essa fúria privatizante que transferiu grande parte do patrimônio público nacional à iniciativa privada a baixos custos, é necessário reconhecer que a reforma da EP e o PROEP foram extremamente coerentes com a lógica neoliberal que os patrocinou, de forma que ao serem analisados a partir dessa perspectiva, aparecem como muito "eficientes".

Existem vários aspectos que demonstram essa "eficiência”. Aqui serão destacados apenas dois deles. O primeiro está relacionado com a lógica da relação entre o PROEP e a Rede Federal de Educação Profissional e Tecnológica. Assim, a função do PROPEP era reestruturar Rede desde o ponto de vista de suas ofertas educacionais, da gestão e das relações empresariais e comunitárias na perspectiva de torná-la competitiva no mercado educacional e, dessa forma, caminhar na direção do aumento da capacidade de autofinanciamento. Assim, o Estado gradativamente se eximiria do seu financiamento.

Dessa forma, mediante projeto, as instituições federais de educação tecnológica (IFETs) receberam aporte de recursos, via PROEP, com o objetivo de reestruturarem-se a fim de assumir a nova função, ou seja, a de buscar arrecadação a partir da prestação de serviços à comunidade na perspectiva de aumentar suas possibilidades de autofinanciamento.

Assim, paralelamente ao aporte de recursos do PROEP, o orçamento das IFETs foi sendo reduzido, uma vez que esse Programa tinha duração determinada, com previsão inicial de 5 anos. Dessa forma, era necessário, segundo a lógica da reforma, que ao final do Programa essas instituições estivessem preparadas para buscar parte de seus orçamentos por meio da venda de cursos à sociedade e de outras formas de prestação de serviços.

Cabe destacar que os critérios de elegibilidade dos projetos institucionais eram extremamente coerentes com a reforma da EPT. Assim, o projeto que apresentasse alguma proposta relacionada com o ensino médio era sumariamente descartado, o que era compatível com a separação do ensino médio da educação profissional e, mais ainda, com o afastamento definitivo das IFETs dessa última etapa da educação básica.

Nessa mesma direção, a Portaria n ${ }^{0}$ 646/1997 determinou que a partir de 1998 a oferta de vagas de cada IFET no ensino médio corresponderia a, no máximo, 50\% das vagas oferecidas nos cursos técnicos de nível médio no ano de 1997, os quais conjugavam ensino médio e educação profissional. Desse modo, na prática, essa simples Portaria determinou a redução da oferta de ensino médio no País - algo flagrantemente inconstitucional, mas que teve plena vigência até 01/10/2003, quando foi publicada no Diário Oficial da União a sua revogação por meio da Portaria n $2.736 / 2003$. 
Merece ainda ressaltar que a manutenção de $50 \%$ da oferta do ensino médio na Rede Federal não era a intenção inicial dos promotores da reforma. Ao contrário, a idéia era extinguir definitivamente a vinculação das IFETs com a educação básica. Na verdade, a manutenção desses $50 \%$ foi fruto de um intenso processo de mobilização ocorrido na Rede, principalmente, entre 17 de abril e 14 de maio de 1997, datas de publicação do Decreto $\mathrm{n}^{0}$ 2.208 e da Portaria $n^{0}$ 646, respectivamente.

Para tratar do segundo aspecto de "eficiência” da reforma segundo a lógica neoliberal, serão mencionados vários fatos que se fortalecem mutuamente: a LDB de 1996 que ratificou e potencializou o âmbito educacional como espaço próprio para o desenvolvimento da economia de mercado; o Decreto $n^{0}$ 2.208/97 define três níveis para a EP: básico; técnico; e tecnológico, sendo que as ofertas do último integram a educação superior, com carga horária mínima significativamente menor que as demais carreiras da educação superior. Para não restar nenhuma dúvida de que as ofertas do nível tecnológico pertencem à educação superior, o Conselho Nacional de Educação os define claramente como cursos de graduação (Parecer CNE/CES 436/2001, Parecer CNE/CP 29/2002 e Resolução CNE/CP 03/2002).

A combinação desses fatos associados à cultura nacional que supervaloriza socialmente 0 diploma de estudos em nível superior, embora não se possa estabelecer uma correspondência precisa entre o status social supostamente conferido por esses diplomas e a repercussão econômica do mesmo para os seus detentores, fez com que houvesse uma proliferação sem precedentes na expansão da oferta de cursos superiores de tecnologia na iniciativa privada, sem controles muito eficientes sobre a qualidade dos mesmos. Na verdade, segundo a lógica inicialmente apresentada o que realmente importava era 0 fortalecimento do mercado educacional e isso, efetivamente, aconteceu.

Evidentemente, não se pode colocar no mesmo lugar comum as ofertas de cursos superiores de tecnologia comercializados em grande parte das instituições privadas e as proporcionadas pela maioria dos CEFETs e outras instituições de educação superior públicas, as quais são concebidas a partir de uma lógica bem distinta da de mercado, entre muitos outros aspectos porque são públicas, gratuitas e, em geral, de boa qualidade.

Como se vê, todo esse contexto do final dos anos 1990 produziu efeitos graves sobre a educação brasileira em todos os níveis. No que se refere à educação básica, a síntese é a explicitação da dualidade entre ensino médio e educação profissional e todas as conseqüências que isso representa.

\section{Uma nova chance para a integração entre ensino médio e educação profissional}

Ao assumir o novo governo federal em 2003, e mesmo antes, já no período de transição, há o recrudescimento da discussão acerca do Decreto $n^{0} 2.208 / 97$, principalmente no que se refere à separação obrigatória entre o ensino médio e a educação profissional.

Esse processo resultou em uma significativa mobilização nos setores educacionais vinculados ao campo da educação profissional, principalmente no âmbito dos sindicatos e dos pesquisadores do domínio da educação e trabalho. Desse modo, durante o ano de 2003 
e até julho de 2004 houve grande efervescência nos debates relativos à relação entre o ensino médio e a educação profissional.

Assim, retoma-se a discussão sobre a educação politécnica ${ }^{6}$, compreendendo-a como uma educação unitária e universal destinada à superação da dualidade entre cultura geral e cultura técnica e voltada para "o domínio dos conhecimentos científicos das diferentes técnicas que caracterizam o processo de trabalho produtivo moderno" (SAVIANI, 2003, p.140, citado por, FRIGOTTO, CIAVATTA e RAMOS, 2005, p. 42) sem, no entanto, voltar-se para uma formação profissional stricto sensu, ou seja, sem formar profissionais em cursos técnicos específicos.

Nessa perspectiva, a escolha por uma formação profissional específica em nível universitário ou não só viria após a conclusão da educação básica nessa visão de politecnia, ou seja, a partir dos 18 anos ou mais de idade.

Entretanto, essa retomada produz reflexões importantes quanto à possibilidade material da implementação da politecncia na educação básica brasileira na perspectiva aqui mencionada, hoje em dia. Tais reflexões e análises permitiram concluir que as características atuais da sociedade brasileira dificultam a implementação da politecnia ou educação tecnológica em seu sentido original, uma vez que, dentre outros aspectos, a extrema desigualdade socioeconômica obriga grande parte dos filhos da classe trabalhadora a buscar a inserção no mundo do trabalho visando complementar o rendimento familiar, ou até mesmo a auto-sustentação, muito antes dos 18 anos de idade.

Assim, a tentativa de implementar a politecnia de forma universal e unitária não encontraria uma base material concreta de sustentação na sociedade brasileira atual, uma vez que esses jovens não podem “se dar ao luxo" esperar até aos 20 anos ou mais para iniciar a trabalhar.

Tais reflexões conduziram ao entendimento de que uma solução transitória e viável é um tipo de ensino médio que garanta a integralidade de uma educação básica, ou seja, que inclua os conhecimentos científicos produzidos e acumulados historicamente pela sociedade, como também objetivos adicionais de formação profissional numa perspectiva da integração dessas dimensões. Essa perspectiva, ao adotar a ciência, a tecnologia, a cultura e o trabalho como eixos estruturantes, contempla as bases em que se pode desenvolver uma educação tecnológica ou politécnica e, ao mesmo tempo, uma formação profissional stricto sensu exigida pela dura realidade da sociedade brasileira.

Essa solução é transitória (de média ou longa duração) porque é fundamental que se avance numa direção em que deixe de ser um "luxo" o fato dos jovens das classes populares poderem optar por uma profissão após os 18 anos de idade. Ao mesmo tempo, é viável porque "o ensino médio integrado ao ensino técnico, sob uma base unitária de formação geral, é uma condição necessária para se fazer a 'travessia' para uma nova realidade" (FRIGOTTO, CIAVATTA e RAMOS, 2005, p. 43).

Foi a partir dessa convergência mínima dentre os principais sujeitos envolvidos nessa discussão que se edificaram as bases que deram origem ao Decreto $n^{0} 5.154 / 04$. Esse

\footnotetext{
${ }^{6}$ Aqui se entende educação politécnica como sinônimo de educação tecnológica,ou seja, uma educação voltada para a superação da dicotomia entre trabalho manual e trabalho intelectual cultura geral e cultura técnica. Uma educação que contribua para o domínio dos fundamentos científicos das diferentes técnicas que caracterizam o processo de trabalho (FRIGOTTO, CIAVATTA e RAMOS, 2005).
} 
instrumento legal, além de manter as ofertas dos cursos técnicos concomitantes e subseqüentes trazidas pelo Decreto $n^{0}$ 2.208/97, teve o grande mérito de revogá-lo e de trazer de volta a possibilidade de integrar o ensino médio à educação profissional técnica de nível médio, agora, numa perspectiva que não se confunde totalmente com a educação tecnológica ou politécnica, mas que aponta em sua direção porque contém os princípios de sua construção.

Em Moura (2006), afirmamos que o Decreto $n^{0}$ 5.154/04 surge na realidade educacional brasileira em um momento de profunda crise do ensino médio. Nele só são oferecidas cerca de $40 \%$ das vagas necessárias. Além disso, falta um sentido, uma identidade para o tipo de ensino médio que é proporcionado à população e, portanto, urge buscá-la.

Essa falta de sentido/identidade está posta em duas dimensões. Uma relativa à sua própria concepção e outra relacionada com o deficiente financiamento público. Esse problema de financiamento contribui para a falta de qualidade do ensino médio, mesmo se nessa análise fosse possível abster-se de considerar os problemas inerentes à concepção. Evidentemente, esse quadro, além de outros aspectos, contribui para que, a cada dia, aumente o número de adolescentes excluídos do ensino médio na faixa etária denominada de "própria" ou "regular".

Além disso, essa etapa educacional é pobre de sentido tanto na esfera pública quanto privada. Nessa perspectiva, é necessário de conferir-lhe uma identidade que possa contribuir para a formação integral dos estudantes. Uma formação voltada para a superação da dualidade estrutural cultura geral versus cultura técnica ou formação instrumental (para os filhos da classe operária) versus formação acadêmica (para os filhos das classes médiaalta e alta) ${ }^{7}$. Esse ensino médio dever ser orientado, tanto em sua vertente dirigida aos adolescentes como ao público da EJA, à formação de cidadãos capazes de compreender a realidade social, econômica, política, cultural e do mundo do trabalho para nela inserir-se e atuar de forma ética e competente, técnica e politicamente, visando contribuir para a transformação da sociedade em função dos interesses sociais e coletivos.

Entretanto, esse tipo de oferta não é amplamente proporcionada à população, pois grande parte das escolas privadas concentram seus esforços em aprovar os estudantes nos vestibulares das universidades públicas - mais bem reconhecidas que as universidades privadas -, adotando uma concepção de educação equivocada, na qual se substitui o todo (formação integral) pela parte (aprovação no vestibular).

Por outro lado, embora haja escolas públicas de excelente qualidade, essa não é a regra geral. Dessa forma, grande parte dessas escolas, nas quais estudam os filhos da classe trabalhadora, tentam reproduzir o academicismo das escolas privadas, mas não conseguem fazê-lo por falta de condições materiais concretas. Deste modo, em geral, a formação proporcionada nem confere uma contribuição efetiva para o ingresso digno no mundo de trabalho nem contribui de forma significativa para o prosseguimento dos estudos no nível superior (MOURA, 2006).

\footnotetext{
${ }^{7}$ Essa dualidade não é fruto do acaso, mas sim da separação entre a educação proporcionada aos filhos das classes média-alta e alta e aquela permitida aos filhos dos trabalhadores. Entretanto, como o objetivo central deste trabalho não está circunscrito a essa oferta educacional, sugerimos, para um maior aprofundamento sobre a matéria, consultar: Frigotto; Ciavatta; Ramos, 2005; CEFET-RN, 2005; e Moura; Baracho; Pereira; Silva, 2005
} 
Uma possibilidade para os filhos da classe trabalhadora é a tentava de ingresso em uma das instituições que compõem a Rede Federal de Educação Profissional e Tecnológica, instituições que historicamente atuam com referência nos vários componentes que constituem a formação integral. Entretanto, tornar-se aluno dessas escolas não é fácil, pois a concorrência para ingresso é muito elevada, uma vez que a quantidade de vagas que podem oferecer é muito menor do que a demanda. Para ilustrar melhor essa afirmação, apresenta-se a distribuição das matrículas no ensino médio e na educação profissional técnica de nível nédio no Brasil, em 2005.

Tabela 1 - Matrícula no ensino médio e na educação profissional técnica de nível médio no Brasil por dependência administrativa

\begin{tabular}{|c|c|c|c|c|c|}
\hline \multirow{2}{*}{$\begin{array}{c}\text { Dependência } \\
\text { administrativa }\end{array}$} & \multirow{2}{*}{$\begin{array}{c}\text { Ensino } \\
\text { Médio } \\
\text { (Regular) }\end{array}$} & \multicolumn{2}{|c|}{ Ensino Médio } & \multirow{2}{*}{$\begin{array}{l}\text { Ensino Médio } \\
\text { (TOTAL) }\end{array}$} & \multirow{2}{*}{$\begin{array}{c}\text { Educação } \\
\text { Profissional } \\
\text { técnica de nível } \\
\text { médio }\end{array}$} \\
\hline & & Presencial & $\begin{array}{c}\text { Semi- } \\
\text { presencial }\end{array}$ & & \\
\hline Brasil & 9.031 .302 & 1.223 .859 & 493.733 & 10.748 .894 & 707.263 \\
\hline Federal & 68.651 & 429 & - & 69.080 & 83.762 \\
\hline Estadual & 7.682 .995 & 1.029 .795 & 455.709 & 9.168 .499 & 188.042 \\
\hline Municipal & 182.067 & 43.470 & 17.061 & 242.598 & 23.545 \\
\hline Privada & 1.097 .589 & 150.165 & 20.963 & 1.268 .817 & 411.914 \\
\hline
\end{tabular}

Fonte: elaboração nossa, a partir de INEP/Censo Escolar 2005.

Ao analisar a Tabela 1, percebe-se que a oferta do ensino médio está concentrada nos sistemas e redes públicas (88,2\% da oferta). Percebe-se também que os cursos técnicos de nível médio correspondem a apenas 6,58\% da oferta total do Ensino Médio. Além disso, a oferta, no âmbito federal, alcança parcos $11,84 \%$ do total de matrículas nesses cursos. E ainda mais, a oferta de cursos técnicos de nível médio é maior no âmbito privado (58,24\%) do que no público (41,76\%), mesmo incluindo-se as esferas municipal, estadual e federal. Finalmente, no que diz respeito ao público da EJA, essa oferta é nula.

Nessa perspectiva, a ampliação da oferta do ensino médio integrado nas instituições públicas de educação pode contribuir para uma efetiva (re)construção de uma identidade própria para o ensino médio brasileiro.

\section{Alguns eixos norteadores para a EP técnica de nível médio integrada ao ensino médio}

A partir das discussões apresentadas nas seções anteriores, podem-se articular alguns pressupostos que nortearão a formação integral que contemple de forma integrada a última etapa da educação básica e uma formação profissional, os quais se encontram expressos a seguir (MOURA, BARACHO, PEREIRA e SILVA, 2006):

a) homens e mulheres como seres histórico-sociais, portanto, capazes de transformar a realidade

Assume-se esse princípio a partir da compreensão do homem como ser histórico-social, portanto, capaz de transformar a realidade, ou seja, um ser que

\footnotetext{
${ }^{8}$ É importante esclarecer que em alguns estados como em São Paulo, por exemplo, a rede Paula Souza atua fortemente na educação tecnológica. Na mesma direção, o estado do Paraná também está ampliando de forma significativa a oferta de educação profissional. Não obstante, essa não é a realidade prenominante no País.
} 
busca a autonomia, a auto-realização e a emancipação através de sua participação responsável e crítica nas esferas sócio-econômico-política. Isto consiste em perceber o homem como um ser capaz de colocar-se diante da realidade histórica para, entre outros aspectos, reagir à coerção da sociedade, questionar as pretensões de validade e de normas sociais, construir uma unidade de interesses e descobrir novas estratégias de atuação solidária (CEFET-RN, 1999, p.47).

Ao texto citado incorporamos a dimensão cultural aos aspectos sociais, econômicos e políticos mencionados, uma vez que a cultura determina e determinada por todos eles, constituindo-se como dimensão central na construção da identidade de um povo assim como a falta de uma cultura própria representa uma ameaça constante à perda dessa identidade e, em conseqüência, da aceitação de identidades subalternas em relação a outras culturas que se pretendem hegemônicas.

Nesse contexto, o homem, portanto, é capaz de se produzir e se modificar na relação com os demais seres humanos, em um movimento dialético sujeito/objeto. Criam e recriam, pela ação consciente do trabalho, sua própria existência (LUKÁCS, 1981, apud SILVA JÚNIOR, 2001).

\section{b) trabalho como princípio educativo}

Esse princípio permite uma compreensão do significado econômico, social, histórico, político e cultural das ciências e das artes. Dessa forma, assumir o trabalho como princípio educativo

[...] implica referir-se a uma formação baseada no processo histórico e ontológico de produção da existência humana, em que a produção do conhecimento científico é uma dimensão. Por exemplo, a eletricidade como força natural abstrata existia mesmo antes de sua apropriação como força produtiva, mas não operava na história. Enquanto era uma hipótese para a ciência natural, era um "nada” histórico até que passa a se constituir como conhecimento que impulsiona a produção da existência humana sobre bases materiais e sociais concretas (RAMOS, 2005).

Nesse sentido, compreende-se que uma prática pedagógica significativa decorre da necessidade de uma reflexão sobre o mundo do trabalho, da cultura desse trabalho, das correlações de força existentes, dos saberes construídos a partir do trabalho e das relações sociais que se estabelecem na produção.

Essa reflexão sobre o trabalho como princípio educativo deve constituir-se em um movimento na busca da unidade teoria e prática, e conseqüentemente na superação da divisão capital/trabalho - uma utopia necessária.

Assim, é fundamental atentar para o fato de que o trabalho como princípio educativo não se restringe ao "aprender trabalhando" ou ao "trabalhar aprendendo". Está relacionado, principalmente, com a intencionalidade de que através da ação educativa os indivíduos/coletivos compreendam, enquanto vivenciam e constroem a própria formação, o fato de que é socialmente justo que todos trabalhem, porque é um direito subjetivo de todos os cidadãos, mas também é uma obrigação coletiva porque a partir da produção de todos se produz e se transforma a existência humana e, nesse sentido, não é justo que muitos trabalhem para que poucos enriqueçam cada vez mais, enquanto outros se tornam cada vez mais pobres e se marginalizam - no sentido de viver à margem da sociedade. 
c) a pesquisa como princípio educativo

A pesquisa contribui para a construção da autonomia intelectual do educando e deve ser intrínseca ao ensino (DEMO, 2000), bem como estar orientada ao estudo e à busca de soluções para as questões práticas do cotidiano do estudante. Nesse sentido, assume-se que a pesquisa, enquanto princípio educativo deve estar presente em todas as ofertas, independentemente, do nível educacional e da faixa etária dos alunos, pois se localiza de forma precípua, no campo das atitudes e dos valores. Sua forma de abordagem deverá ser adequada a todos os níveis e modalidades de ensino, através de estratégias, métodos e objetivos próprios de cada oferta e do amadurecimento intelectual de cada grupo de estudantes.

A pesquisa deve instigar o estudante no sentido da curiosidade em direção ao mundo que 0 cerca, gerar inquietude, para que ele não incorpore "pacotes fechados" de visão de mundo, de informações e de saberes, quer sejam do senso comum (saber cotidiano), escolares ou científicos. Esse tipo de atitude, quando despertada nas primeiras fases escolares, contribui para que, nas faixas etárias e níveis educacionais mais avançados, o estudante possa formular questões de investigação no campo mais formal, quer seja na sua forma aplicada ou na denominada pesquisa de base ou acadêmica.

Na esfera dos valores, assume-se que a pesquisa aplicada e o desenvolvimento tecnológico devem estar voltados para a produção de bens e serviços que tenham como finalidade melhorar as condições da vida coletiva e não apenas de produzir bens de consumo para fortalecer o mercado e, em conseqüência, privilegiar o valor de troca em detrimento do valor de uso, concentrando riqueza e aumentando o fosso entre os incluídos e os excluídos (MOURA, 2004).

Evidentemente, a pesquisa também pode e deve estar orientada a aspectos mais acadêmicos das ciências da natureza, sociais e/ou aplicadas, mas sempre tendo em consideração a que interesses correspondem e quem serão os prováveis beneficiários dos possíveis resultados alcançados.

Diante do exposto, é necessário conceber essas ofertas a partir da unidade ensino/pesquisa, a qual colabora para edificar a autonomia dos indivíduos, isto é, o desenvolvimento, entre outros aspectos, das capacidades de ao longo da vida aprender, interpretar, analisar, criticar, refletir, buscar soluções e propor alternativas, potencializadas pela investigação e pela responsabilidade social assumida. O estudante, na perspectiva Freireana, deixa de ser um "depósito" de conhecimentos produzidos e transmitidos por outros e passa a construir, desconstruir e reconstruir suas próprias convicções a respeito da ciência, da tecnologia, do mundo e da própria vida.

d) a realidade concreta como uma totalidade, síntese das múltiplas relações

A realidade é um todo dialético e estruturado, produzido por um conjunto de fatos que se inter-relacionam e que podem ser compreendidos, mas não pré-determinados ou previstos (CIAVATTA; FRIGOTTO; RAMOS, 2005). Nesse sentido, o currículo integrado deve possibilitar ao estudante a compreensão do contexto no qual está inserido, para que possa intervir nele, em função dos interesses coletivos. 
e) a interdisciplinaridade, contextualização e flexibilidade

As Diretrizes Curriculares Nacionais explicitam como princípios, dentre outros, a interdisciplinaridade, a contextualização, e a flexibilidade, os quais devem estar contemplados na formulação e no desenvolvimento do projeto pedagógico de cada instituição de ensino. Entretanto, é necessário que cada instituição análise, critique, sintetize e ressignifique o que se propõe nessas diretrizes, à luz de teorias educacionais e das visões dos sujeitos envolvidos no processo de ensinar e de aprender.

Nesse sentido, para desenvolver uma postura verdadeiramente interdisciplinar, é necessário assumir, a priori, os não saberes e as limitações individuais na própria disciplina que o professor leciona. Assim, a interdisciplinaridade não pode ser entendida como a fusão de conteúdos ou de metodologias, mas sim como interface de conhecimentos parciais específicos que têm por objetivo um conhecimento mais global. É, pois, uma nova postura no fazer pedagógico para a construção do conhecimento.

Nessa perspectiva, a interdisciplinaridade implica uma mudança de atitude que se expressa quando o indivíduo analisa um objeto a partir do conhecimento das diferentes disciplinas, sem perder de vista métodos, objetivos e autonomia próprios de cada uma delas.

Assim, a interdisciplinaridade é um exercício coletivo e dinâmico que depende das condições objetivas das instituições, do envolvimento e do compromisso dos agentes responsáveis pelo processo ensino-aprendizagem.

Portanto, sugere-se, como uma forma (entre outras) para concretizar esse princípio, a implementação de projetos integradores que visam, sobretudo, articular e inter-relacionar os saberes desenvolvidos pelas disciplinas em cada período letivo, contribuir para a construção da autonomia intelectual dos alunos, por meio da pesquisa, assim como formar atitudes de cidadania, de solidariedade e de responsabilidade social. O referido projeto deverá estar vinculado à busca de soluções para as questões locais e regionais, sem perder de vista os contextos nacional e mundial, potencializando o uso das tecnologias com responsabilidade social, sendo, portanto, contextualizado a cada realidade específica.

Dessa forma, não são os conteúdos isolados que devem gerar os projetos de estudo, mas a necessidade de sua articulação e inter-relação, em função do sentido social e pedagógico dos objetivos propostos em cada projeto. Portanto, estudantes e professores terão condições de construir, desconstruir e reconstruir seus conhecimentos.

Ainda torna-se relevante ressaltar que todo conhecimento significativo é contextualizado, produzido e utilizado em contextos específicos. Contextualizar a aprendizagem significa superar a aridez das abstrações científicas para dar vida ao conteúdo escolar relacionando-o com as experiências passadas e atuais vivenciadas pelos estudantes/educadores, projetando uma ponte em direção ao seu futuro e ao da realidade vivencial.

Por outro lado, é preciso estar alerta para o fato de que contextualizar a aprendizagem e torná-la significativa não implica em abrir mão dos saberes escolares - base para a construção do conhecimento científico, em benefício daqueles construídos/adquiridos através da experiência vivencial. Evidentemente, é importante considerar os últimos, mas, muitas vezes, é necessário partir deles para desconstruí-los apoiados nos saberes escolares, buscando explicações na ciência que possibilitem ao estudante ressignificá-los, ou mesmo 
descartá-los, pelo confronto entre eles e os saberes escolares - alicerçados nas ciências humanas, naturais e sociais.

Partindo desse pressuposto, assume-se que a formação dos estudantes deve ser na perspectiva de uma prática social mais ampliada, incluindo a formação para o trabalho e a vida em sociedade em tempo real, pois a vida não pára enquanto o aluno está na escola. Ao contrário, esse é, por excelência, um espaço de socialização e de construção do caráter e da personalidade de todos que compartilham esse ambiente.

A contextualização, portanto, deve ser compreendida como uma estratégia de problematização das condições sociais, históricas, econômicas e políticas e para aplicar os saberes escolares. Isso supõe conhecer as limitações e potencialidades do conhecimento científico e tecnológico e suas relações com outros tipos de saberes. Nessa perspectiva, o conteúdo ganha sentido em razão da relação que se estabelece entre o que é ensinado/aprendido e o conhecimento situado numa dada realidade.

Outro princípio básico e que deve constituir-se num eixo norteador é a flexibilidade, a qual deve ser entendida como uma das bases epistemológicas relevantes do currículo, porque vivemos, mais do que nunca, numa sociedade onde a única certeza é a de que o futuro é incerto. Isso não significa que devamos cruzar os braços e esperar que o futuro simplesmente chegue.

Além disso, é imperioso entender que a flexibilidade aqui tratada não pode ser confundida com aligeiramento e precarização da formação humana. Ao contrário, devemos assumir a responsabilidade com a formação de cidadãos críticos, reflexivos, éticos e comprometidos com as transformações sociais e coletivas voltadas para a construção de uma sociedade justa e igualitária - o que jamais poderá ser alcançado a partir de uma perspectiva aligeirada e reducionista. Evidentemente, isso não significa que se possa prever o futuro e garantir que os objetivos traçados serão alcançados de forma linear, mas sim, que eles deverão ser perseguidos, apesar das dificuldades e das incertezas próprias da contemporaneidade.

Portanto, a mudança, assim como a expectativa de que ela ocorra, é o que gera a necessidade crescente de uma postura flexível, aberta, pois essa mudança está presente em nossa realidade, em nossa corporeidade, já que é parte intrínseca da natureza da matéria. Está presente tanto nas circunstâncias que nos envolvem como também em nossas estruturas biológicas. Isto ocorre pelo fato de a mudança fazer parte da própria dinâmica organizadora da vida.

Dessa maneira, ela está presente nos processos de construção do conhecimento, na aprendizagem, na maneira como interpretamos a realidade, no modo de construir, desconstruir e reconstruir conhecimentos. Isto ocorre porque os processos interpretativos possuem natureza dialeticamente complexa e intrinsecamente re-construtiva.

É a mudança implícita na re-construção do conhecimento, no diálogo sujeito/objeto, nos processos auto-organizadores da vida que permite o desenvolvimento da autonomia e a emancipação do sujeito (FREIRE, 1987; 1996). É ela que está também presente na dinâmica não-linear ambivalente da aprendizagem. Muitas vezes, a mudança acontece ao rever-se o aprendido, ao reconhecer-se o próprio erro, ao construir-se um novo significado e isto é muito importante em termos hermenêuticos, pois a re-construção do conhecimento e a re-interpretarão de algo supõe a sua des-construção. 
Além disso, o currículo deve reforçar a consciência de nossa incompletude humana, indicando que somos seres históricos inacabados em processo constante de vir a ser (FREIRE, 1996) e, portanto, abertos constantemente à mudança, à reorganização e à autoorganização que é a capacidade que todo sistema vivo possui de se auto-transformar continuamente e de se auto-produzir. Para tanto, interage com o meio exterior de onde extrai energia, matéria e informação, elementos constituintes de sua dinâmica organizacional, inclusive, para interferir nos rumos desse meio exterior.

Finalmente, a flexibilidade implica na operacionalização do processo ensino-aprendizagem em que o estudante tenha diferentes perspectivas na sua trajetória acadêmica, permitindolhe avançar quando demonstrar condições para isso ou ter estudos de complementação necessários ao desenvolvimento nas áreas de conhecimentos científicos e tecnológicos.

\section{Algumas proposições para a organização curricular do ensino médio integrado à EP técnica de nível médio}

Ainda seguindo Moura, Baracho, Pereira e Silva (2006), assumimos que essa nova forma de organização deve contemplar conhecimentos, capacidades e atitudes específicos não só de uma ocupação, mas, também, da área profissional da qual deriva. Nessa linha de raciocínio, o currículo precisa ser materializado em um projeto político-pedagógico, do qual devem derivar tantos planos de cursos quantas forem as ofertas educacionais proporcionadas pela instituição. E, como forma de contemplar nos planos de cursos os princípios citados anteriormente, faz-se necessário que a matriz curricular expresse uma organização que possibilite uma base sólida de conhecimentos científicos e tecnológicos, levando ainda em consideração outros aspectos como:

a) garantia de financiamento público para apoiar as ações a serem desenvolvidas;

b) plano de capacitação permanente de docentes, técnico-administrativos e gestores;

c) infra-estrutura adequada de salas de aula, laboratórios, biblioteca, espaço para atividades artístico-culturais;

d) organização curricular diferenciada para os alunos do turno noturno;

e) busca de um diálogo com interlocutores externos ao próprio sistema acadêmico;

f) colaboração com empresas e instituições para a realização de estágios curriculares;

g) plano de implementação, acompanhamento e avaliação dos cursos.

São várias as possibilidades de organização dos currículos dos cursos técnicos integrados. Assim, é muito importante que cada sistema de ensino, apoiado na participação coletiva dos sujeitos envolvidos e nas teorias educacionais busque a respectiva solução, pois ninguém mais do que o próprio grupo, o próprio coletivo conhece a sua realidade e, portanto, está mais habilitado para tomar decisões a respeito do currículo que vai levar à prática. A partir dessas considerações, apresentamos uma dessas possibilidades, a modo de exemplo, sujeita a análises, críticas, sugestões, revisões ou substituição por outra possibilidade compatível com a realidade de cada escola e, nunca, como um modelo prescritivo.

Feitos esses esclarecimentos, uma das possibilidades que pode orientar a organização curricular dos cursos técnicos integrados é a estruturação por meio de uma base de 
conhecimentos científicos e tecnológicos, distribuídas em quatro séries anuais ${ }^{9}$, articuladas em quatro núcleos que interagem permanentemente:

a) um núcleo comum, que integra disciplinas das três áreas de conhecimento do Ensino Médio (Linguagens e Códigos e suas Tecnologias, Ciências Humanas e suas Tecnologias e Ciências da Natureza, Matemática e suas Tecnologias);

b) uma parte diversificada, que integra disciplinas voltadas para uma maior compreensão das relações existentes no mundo do trabalho e para uma articulação entre este e os conhecimentos acadêmicos;

c) formação profissional, que integra disciplinas específicas de cada curso;

d) prática profissional.

Esses núcleos acima nominados não se constituem em compartimentos estanques ou módulos isolados. Na verdade, essa forma de apresentar a organização curricular é uma didatização, pois os núcleos estão inter-relacionados e em constante diálogo proporcionado pelo desenvolvimento de projetos interdisciplinares ou outras metodologias que estimulem o diálogo entre as disciplinas que os compõem.

Além disso, as disciplinas deverão estar articuladas através de um eixo integrador que corresponda à área profissional na qual está situado cada curso. Também contribui para a integração o fato de que os alunos estão imersos em um ambiente de estudos relativos às ciências, às letras e às artes juntamente com a formação profissional tanto na própria área, como em outras áreas profissionais, em função de todo um fazer institucional.

Além dessa e de outras possibilidades, esses cursos poderão ser organizados através das áreas de conhecimentos do ensino médio: Linguagens e Códigos e suas Tecnologias, Ciências da Natureza, Matemática e suas Tecnologias e Ciências Humanas e suas Tecnologias. Essas áreas poderão aglutinar os conhecimentos das disciplinas relativas ao núcleo comum, parte diversificada e da parte profissionalizante do currículo.

Assim, uma adequada organização, associada a uma prática pedagógica condizente com os princípios anteriormente explicitados, possibilitará a construção da unidade dos conhecimentos trabalhados em cada área profissional, contribuindo para uma formação integrada e integral que permita aos seus sujeitos:

a) conhecer e utilizar as formas contemporâneas de linguagem, com vistas ao exercício da cidadania e à preparação para o trabalho, incluindo a formação ética e o desenvolvimento da autonomia intelectual e do pensamento crítico;

b) compreender a sociedade, sua gênese e transformação e os múltiplos fatores que nela intervêm, como, produtos da ação humana e do seu papel como agente social;

c) ler, articular e interpretar símbolos e códigos em diferentes linguagens e representações, estabelecendo estratégias de solução e articulando os conhecimentos das várias ciências e outros campos do saber;

\footnotetext{
${ }^{9}$ Já existem algumas experiências de cursos desenvolvidos em 3 anos. Situação em que o aluno recebe maior carga horária diária. Evidentemente isso é possível, entretanto, ressaltamos o fato de que ao organizar o currículo não se pode considerar apenas a possibilidade da escola organizar os seus próprios tempos e espaços, mas também, o tempo de maturação e aprendizagem dos alunos, pois esses sujeitos que participam ativamente da re-construção desses saberes e conhecimentos, o que exige um tempo próprio.
} 
d) compreender os fundamentos científico-tecnológicos dos processos produtivos, relacionando teoria e prática nas diversas áreas do saber e em sua área de formação profissional específica;

e) adquirir conhecimentos e capacidades próprios de cada curso específico.

\section{Considerações finais}

Diante de todo o exposto, é fundamental assumir que no atual momento histórico, umas das formas de construir um sentido para o ensino médio é buscando sua integração com a educação profissional técnica de nível médio ${ }^{10}$. Para isso, é fundamental a sua ampliação gradativa de forma gratuita, laica e com qualidade nos sistemas públicos de educação.

Entretanto, apesar dessa necessária ampliação, há que se cuidar para que o processo ocorra de forma planejada e coordenada entre as distintas esferas de governo. Nesse sentido, é fundamental que se estabeleça um eficiente regime de mútua cooperação entre os sistemas estaduais, municipais e o federal. Igualmente importante é que sejam definidas e disponibilizadas fontes de financiamento. Que sejam constituídos os quadros de professores e que esses sejam adequadamente formados. Se isso não ocorrer, serão reproduzidos os erros do passado.

Finalmente, é preciso ter claro que essa gradativa expansão da oferta de ensino médio integrado à educação profissional técnica de nível médio não visa, em princípio, a sua universalização. Entretanto, objetiva sedimentar as bases, plantar as sementes de uma futura educação politécnica ou tecnológica, essa sim deverá ter caráter universal (além de ser pública, gratuita, laica e de qualidade), mas só poderá ser implantada quando as condições objetivas da sociedade brasileira assim o permitir. Enquanto isso, a prioridade deverá ser consolidar essa oferta que conjuga ensino médio e educação profissional na perspectiva da formação integral dos sujeitos que a ela tiverem acesso.

\section{Referências}

BRASIL. CONSTITUIÇÃO DA REPÚBLICA FEDERATIVA DO BRASIL DE 1988. Disponível

https://www.planalto.gov.br/ccivil_03/Constituicao/Constitui\%C3\%A7ao.htm. Acesso 23.10.2006.

CONSTITUIÇÃO DOS ESTADOS UNIDOS DO BRASIL (DE 10 DE $\begin{array}{lllll} & \text { NOVEMBRO } & \text { DE } & \text { 1937). } & \text { Disponível }\end{array}$ https://www.planalto.gov.br/ccivil_03/Constituicao/Constitui\%C3\%A7ao37.htm. Acesso 23.10.2006.

CONSTITUIÇÃO DA REPÚBLICA DOS ESTADOS UNIDOS DO BRASIL

(DE 16 DE $\quad$ JULHO DE 1934). Disponível em https://www.planalto.gov.br/ccivil_03/Constituicao/Constitui\%C3\%A7ao34.htm. Acesso 23.10.2006.

MINISTÉRIO DA EDUCAÇÃO. Programa de Integração da Educação Profissional Técnica de Nível Médio Integrada ao Ensino Médio na Modalidade de

\footnotetext{
${ }^{10}$ Essa é uma travessia para uma futura educação tecnológica ou politécnica, na qual não se objetiva uma formação profissional stricto sensu, mas uma formação ampla que permita ao cidadão atuar em qualquer área profissional. Para um maior aprofundamento ver: FRIGOTTO, G.; CIAVATTA, M.; e RAMOS, M. N. (Orgs.) Ensino médio integrado: concepção e contradições. São Paulo: Editora Cortez, 2005.
} 
Educação de Jovens e Adultos - PROEJA. Documento Base. Brasília, 2006a. Disponível em <http://portal.mec.gov.br/setec.> Acesso 07.04.2006.

Lei no 9.394, de 20 de dezembro de 1996. Institui as diretrizes e bases da educação nacional. Brasília, DF: 20 de dezembro de 1996.

. Lei $\mathbf{n}^{\mathbf{0}} \mathbf{4 . 0 2 4}$, de 20 de dezembro de 1961. Fixa as diretrizes e bases da educação nacional. Brasília, DF: 20 de dezembro de 1961. Disponível em < https://www.planalto.gov.br/ccivil_03/Leis/L4024.htm.> Acesso 07.04.2006.

Lei 5.692, de 11 de agosto de 1971. Fixa Diretrizes e Bases para o ensino de $1^{\circ}$ e $2^{\circ}$ graus, e dá outras providências. Disponível em http://www.pedagogiaemfoco.pro.br/l5692_71.htm. Acesso 07.04.2006.

Decreto $\mathbf{n}^{\mathbf{0}} \mathbf{2 . 2 0 8}$, de 17 de abril de 1997 . Regulamenta o $\S 2^{\circ}$ do art. 36 e os arts. 39 a 42 da Lei $n^{\circ}$ 9.394, de 20 de dezembro de 1996, que estabelece as diretrizes e bases da educação nacional. Brasília, DF: 17 de abril de 1997. Disponível em https://www.planalto.gov.br/ccivil_03/decreto/D2208.htm. Acesso 07.04.2006.

Decreto $\mathbf{n}^{0}$ 5.154, de 23 de julho de 2004. Regulamenta o § 2을 do art. 36 e os arts. 39 a 41 da Lei no 9.394, de 20 de dezembro de 1996, que estabelece as diretrizes e bases da educação nacional. Brasília, DF: 23 de julho de 2004. Disponível em https://www.planalto.gov.br/ccivil_03/_Ato2004-2006/2004/Decreto/D5154.htm. Acesso 07.04.2006.

. CONSELHO NACIONAL DE EDUCAÇÃO. Parecer CNE/CEB n⿳ 16/99, de 05 de outubro de 1999. Dispõe sobre as Diretrizes Curriculares Nacionais para a Educação Profissional de Nível Técnico. Disponível em < http://portal.mec.gov.br/cne/index.php?option=content\&task=view\&id=147\&Itemid=206\# $\underline{1999 B}>$. Acesso 20.10.2006.

CONSELHO NACIONAL DE EDUCAÇÃO. Parecer CNE/CP n 29/2002, Dispõe sobre as Diretrizes Curriculares Nacionais Gerais para a organização e o funcionamento dos cursos superiores de tecnologia. Disponível em http://portal.mec.gov.br/cne/arquivos/pdf/cp29.pdf. Acesso 23.10.2006.

CONSELHO NACIONAL DE EDUCAÇÃO. Resolução CNE/CP nº3/2002, Institui as Diretrizes Curriculares Nacionais Gerais para a organização e o funcionamento dos cursos superiores de tecnologia. Disponível em http://portal.mec.gov.br/cne/arquivos/pdf/CP032002.pdf. Acesso 23.10.2006.

. CONSELHO NACIONAL DE EDUCAÇÃO. Parecer CNE/CES no 436/2001. Disponível em http://portal.mec.gov.br/cne/arquivos/pdf/CES0436.pdf. Acesso 23.10.2006.

CENTRO FEDERAL DE EDUCAÇÃO TECNOLÓGICA DO RIO GRANDE DO NORTE. Projeto político-pedagógico do CEFET-RN: um documento em construção. Natal: CEFET-RN, 2005.

Projeto de reestruturação curricular. Natal: CEFET-RN, 1999.

CIAVATTA, M.; FRIGOTTO, G.; RAMOS, M. N. A gênese do Decreto nº 5.154/2004: um debate no contexto controverso da democracia restrita. In: Trabalho necessário. Revista Eletrônica do neddate. Disponível em $<$ http://www.uff.br/trabalhonecessario/MMGTN3.htm>. Acesso 09.08.2005

DEMO, P. Educar pela pesquisa. 4 ed. Campinas: Autores Associados, 2000. 
FREIRE, P. Pedagogia do Oprimido. 17 ed. Rio de Janeiro: Paz e Terra, 1987.

Pedagogia da autonomia: saberes necessários à prática educativa. Rio de Janeiro:Paz e Terra, 1996.

FAVERO, O. (Org.). A educação nas constituintes brasileiras 1823-1988. 2 ed. São Paulo: Editora Autores Associados, 2001

FREITAG, B. Escola, estado e sociedade. São Paulo: Moraes, 2000.

GERMANO, J. W. Estado Militar e educação no Brasil. São Paulo: Cortez, 1993.

KUENZER, A. Z. Ensino médio e profissional: as políticas do Estado neoliberal. São Paulo: Cortez, 1997, 104p.

MACIEL, C. M. O lugar da escola técnica frente às aspirações do Mercado de trabalho. 2005. 116f. Dissertação (Mestrado em Antropologia e Sociologia). Instituto de Filosofia e Ciências Sociais da Universidade Federal do Rio de Janeiro. Rio de Janeiro, 2005.

MOURA, D. H. Reflexões sobre ética, estado brasileiro e educação. IN: HOLOS. Ano XXII, $\mathrm{n}^{0}$ 2. Revista eletrônica do CEFET-RN. Disponível em http://www.cefetrn.br/dpeq/holos/. Acesso 10.05.2006.

MOURA, D. H. Sociedade, educação, tecnologia e os usos das TIC nos processos educativos. In: Trabalho necessário. Revista Eletrônica do neddate. Disponível em <http://www.uff.br/trabalhonecessario/>. Acesso 15.08.2004.

MOURA, D. H. e CAMELO, G. L. P. Interfaces legais, políticas, pedagógicas e administrativas na trajetória do CEFET-RN. Natal: mimeo, 2006.

MOURA, D. H., BARACHO, M. G., PEREIRA, U. A. e SILVA, A. F. Algumas reflexões e proposições acerca do ensino médio integrado à educação profissional técnica de nível médio. IN: Ensino médio integrado à educação profissional. Programa Salto para o Futuro. TV escola. Boletim 07. Maio/junho de 2006. Disponível em < http://www.tvebrasil.com.br/salto/> Acesso 20.10.2006.

NISKIER, A. A nova Escola. Rio de Janeiro: BLOCH, 1974.

PAIVA, J. Educação de Jovens e Adultos: direito, concepções e sentidos. Tese de Doutoramento em Educação. Programa de Pós-Graduação em Educação da Universidade Federal Fluminense. Niterói: UFF, 2005.

RAMOS, M. N. Possibilidades e desafios na organização do currículo integrado. IN: FRIGOTTO, G.; CIAVATTA, M.; e RAMOS, M. N. (Orgs.) Ensino médio integrado: concepção e contradições. São Paulo: Editora Cortez, 2005, p. 106-127.

SILVA JÚNIOR, J. R. Reformas educacionais, reconversão produtiva e a constituição de um novo sujeito. In: GENTILI, P.; FRIGOTTO, G. (orgs.). A cidadania negada. 2 ed. São Paulo: Cortez, 2001. 